\title{
KESINAMBUNGAN DAN PROSES TRANSMISI KELENTANGAN DALAM KONTEKS RITUAL MASYARAKAT DAYAK BENUAQ DI KALIMANTAN TIMUR
}

\author{
Eli Irawati ${ }^{1}$,Wisma Nugraha Ch. ${ }^{2}$, dan Timbul Haryono ${ }^{3}$ \\ Program Studi Pengkajian Seni Pertunjukan dan Seni Rupa, \\ Universitas Gadjah Mada Yogyakarta
}

\begin{abstract}
Transmission is one of the notable issues due to its role in the continuity of localtraditional musical practices across the globe. This paper aims to explore the transmission of kelentangan music and its link with the continuity of the music.Using ethnographic approach, this study deal with kelentangan not merely as musical sound but as a results of music making and varius activities in the daily life of Benuaq people. This study shows that, firstly, transmission of knowledge and skilss od kelentangan occurred between penu'ung to penu'ung and between penu'ung and its audiences. The second, kelentangan is closely tied with the extra-musical contexts. There has been no specific learning institution in Dayak Benuaq culture to the teaching and learning of the music. The third, the transmission of kelentangan not only generates the regenerations of its musicians, but also of its audiences. Last but not least, transmission has been one of notable elemets of the continuity of music. Transmission however cannot be operating in itself. It instead closely tied to various extra-musical context and activities in the life of Benuaq people, ranging from profane to the sacred one. In other words, it is located in the ecosystem of culture of Benuaq people. The transmission of kelentangan takes place in part due Benuaq peopleare still remain conduct their culture in line with their ancestors life in the past. Thus, to maintain the continuity of kelentangan music means to maintain the ecosystem of culture of Benuaq people.
\end{abstract}

Keywords: Kelentangan, Transmission, Continuity, Contexts, Ecosystem of Culture

\begin{abstract}
Abstrak
Transmisi merupakan salah satu isu yang cukup penting dalam kehidupan musik-musik lokal-tradisional di berbagai penjuru dunia, utamanya di era globalisasi seperti dewasa ini.Ini disebabkan karena transmisi merupakan salah satu aspek yang menunjang keberlangsungan atau kesinambungan suatu praktik musikal.Tulisan ini bertujuan mengurai transmisi dan kaitannya dengan kesinambungan praktik kelentangan dalam masyarakat Dayak Benuaq di Kalimantan Timur.Dengan menggunakan pendekatan \footnotetext{
Pogung Yogyakarta. Email: eli_irawati9@yahoo.co.id. HP: 081804167028.

${ }^{2}$ Promotor di Prodi PSPR Sekolah Pascasarjana UGM. Gedung Lengkung Jalan Teknika Utara, Pogung Yogyakarta.

${ }^{3}$ Co Promotor di Prodi PSPR Sekolah Pascasarjana UGM. Gedung Lengkung Jalan Teknika Utara, Pogung Yogyakarta.
}

${ }^{1}$ Mahasiswa S-3 di Prodi PSPSR, Sekolah Pascasarjana UGM. Gedung Lengkung Jalan Teknika Utara,
\end{abstract}


etnografis, studi ini menyoroti praktik kelentangan tidak hanya sebagai bunyi musik, melainkan sebagai hasil dari aktivitas berkesenian masyarakat Benuaq serta juga aktivitas-aktivitas lainnya dalam kehidupan masyarakat itu.Analisis terhadap data yeng diperoleh di lapangan menunjukkan bahwa, pertama, transmisi terjadi antara penu'ung dengan penu'ung dan penu'ung dengan publik.Kedua, kelentangan adalah praktik musik yang sangat terikat konteks, sehingga transmisinya pun terjadi dalam konteks tertentu, dan tidak ada pranata pembelajaran yang khusus.Ketiga, transmisi tidak hanya menyebabkan terjadinya regenerasi pelaku, melainkan juga regenerasi publiknya.Terakhir, transmisi memang merupakan bagian penting dalam kesinambungan kelentangan. Namun, transmisi tidak dapat berdiri sendiri, melainkania juga ditopang oleh konteksnya, yakni kegiatan profan dan ritual-sakral yang masih dipegang teguh oleh masyarakat Benuaq sebagai salah satu wujud bahwa mereka masih memegang teguh warisan leluhur. Jadi, kesinambungan kelentangan tidak semata-mata bergantung pada transmisi, sebab transmisi tidak dapat berdiri sendiri, melainkan merupakan salah satu bagian dari ekosistem budaya.Menjaga kesinambungan kelentangan berarti harus menjaga eosistem budayanya, dan transmisi termasuk salah satu aspek di dalamnya.

Kata Kunci: Kelentangan, Dayak Benuaq, Transmisi, Kesinambungan, Konteks, dan Ekosistem Budaya.

\section{Pendahuluan}

Transmisi dipandang menjadi salah satu aspek pentingbagi keberlangsungan musik-musik lokal-tradisional di berbagai belahan dunia, terutama dalam era globalisasi dewasa ini. Globalisasi telah menjadi bahan pembicaraan yang umum, baik dalam realita kehidupan sehari-hari maupun dalam diskursus akademis. Fenomena ini memiliki beragam implikasi dalam kehidupan kelompok- kelompok masyarakat dan kebudayaan di berbagai penjuru dunia, salah satunya ialah cultural greyout, yakni memudar atau menghilangnya batas-batas yang kaku antara satu kebudayaan dengan kebudayaan lainnya. Keadaan ini antara lain bermuara pada terjadinya penyeragaman unsur-unsur kebudayaan. Implikasi ini, jika dicermati, cenderung berkonotasi negatif. Masyarakat dan kebudayaan di dunia yang beragam dan masing-masing memiliki kekhasan, lambat laun menjadi seragam karena terjadinya saling tukar-pinjam elemenelemen budaya. Ini sejalan dengan pandangan Martin Albrow, yang menyatakan bahwa globalisasi "refers to all those processes by which the peoples of the world are incorporated into a single world society, global society" (Pieterse, 2009: 65). Tentu 
tidak ada yang salah soal menjadi seragam, tapi yang jelas keberagaman yang tadinya ada mulai terkikis dan tidak menutup kemungkinan suatu saat akan hilang. Bagi sebagian kalangan, hilangnya keberagaman ini dipandang sebagai suatu bentuk kerusakan.

Seperti halnya dua sisi mata uang, bagaimanapun juga, globalisasi memiliki implikasi positif dalam kehidupan masyarakat dan kebudayaan di dunia, misalnya bagaimana globalisasi memicu sekaligus memberi ruang bagi kebudayaan-kebudayaan di dunia untuk ikut serta berekspresi dalam ranah global. Sekarang, suatu praktik budaya dari satu kelompok masyarakat bisa dengan mudah diakses oleh orang-orang dari berbagai belahan dunia dengan sentuhan jari saja. Artinya, upaya untuk memperkenalkan budaya tidak lagi sesulit beberapa dekade yang lalu.

Terlepas dari implikasi positifnya, namun demikian, globalisasi agaknya sudah terlanjur lebih sering diasosiasikan dengan konotasi negatif, yakni "mengancam kebudayaan." Pandangan semacam ini juga dimiliki oleh sebagian etnomusikolog, sehingga mereka memandang perlu untuk turut mendukung kesinambungan praktikpraktik musikal dari berbagai kelompok masyarakat dan kebudayaan di berbagai belahan dunia agar tidak terlindas arus globalisasi. Tetapi, ini tidak serta-merta berarti bahwa etnomusikolog menolak realita perubahan dalam kelangsungan hidup musikmusik di dunia. Sebaliknya, mereka berupaya mendorong masyarakat untuk tetap menghargai musik yang dimiliki dan kemudian mencari cara bagaimana mengadaptasikannya dengan perubahan yang terjadi, sebab perubahan adalah sesuatu yang niscaya. Dalam konteks perubahan yang ditimbulkan oleh globalisasi dan dampaknya yang mengancam kelangsungan hidup musik-musik lokal-tradisional di dunia, transmisi menjadi salah satu persoalan yang patut untuk diangkat. Transmisi mempengaruhi bagaimana suatu praktik musik dapat bertahan dalam perjalanan waktu.

Signifikansi transmisi dalam keberlangsungan suatu praktik musikal agaknya telah sejak lama disadari oleh para etnomusikolog, sehingga mereka telah melakukan studi terhadap persoalan ini dalam berbagai kebudayaan, baik secara sistematis maupun sebagai komponen dalam penelitian mereka (Campbell, 2011: 82). Apabila transmisi berjalan dengan baik, maka apa yang ditransmisikan dapat terus bertahan dan eksis dari waktu ke waktu. Sebaliknya, transmisi yang tidak berjalan baik akan turut mempengaruhi hilangnya sesuatu yang ditransmisikan itu. Dengan demikian, persoalan 
transmisi menjadi penting untuk dipahami dalam kaitannya dengan kesinambungan suatu praktik budaya, tidak terkecuali musik.

Transmisi juga menjadi isu penting dalam kehidupan praktik-praktik kebudayaan lokal di Indonesia. Mayoritas — atau bahkan mungkin semua—kebudayaan di Indonesia hidup dan diwariskan secara lisan. Oleh karena itu, transmisi benar-benar harus berjalan dengan baik dan langsung dari satu genersi ke generasi berikutnya agar praktik kebudayaan itu tetap bertahan. Terputus satu generasi saja bisa jadi akan memutus keberlangsungan praktik itu, karena bisa dikatakan tidak ada media yang bisa digunakan untuk menyimpan atau "mengawetkan" informasi-misalnya catatan, notasi, dan sebagainya-tentang praktik-praktik budaya. Ini berlaku untuk semua praktik kebudayaan, termasuk musik, di semua kelompok masyarakat.

Seperti halnya praktik-praktik musik dalam berbagai kebudayaan di Nusantara, tidak diketahui secara pasti sejak kapan kelentangan ada dalam kehidupan masyarakat Dayak Benuaq - atau setidaknya belum ada sumber yang menyebutkan sejak kapan tradisi ini ada. Yang pasti, masyarakat pemiliknya meyakini bahwa kelentangan telah ada sejak lama. Artinya, kelentangan sudah melewati kurun waktu yang panjangmeskipun tidak diketahui seberapa panjang-hingga bisa tetap ada sekarang ini. Keberadaan kelentangan ini kemudian memunculkan pertanyaan: Mengapa kelentangan bisa bertahan hingga saat ini? Setidaknya ada dugaan yang bisa diajukan sebagai jawaban: karena masih dibutuhkan dan memiliki fungsi sosial yang penting dalam kehidupan masyarakatnya, sejalan yang dikemukakan oleh Timbul Haryono (Timbul, 2008: 132) dan ditunjang dengan transmisinya-dari satu generasi ke generasi berikutnya, sampai pada generasi saat ini-berjalan dengan baik. Kedua jawaban di atas pada dasarnya saling terkait satu sama lain, yang dapat dikemukakan dalam pernyataan seperti berikut: kelentangan terus ditransmisikan-dari satu generasi ke generasi berikutnya, atau dari satu orang ke orang lainnya dalam satu generasi—karena ia masih dibutuhkan alias masih memiliki fungsi dalam kehidupan masyarakatnya.

Tulisan ini bertujuan untuk mengurai bagaimana kaitan transmisi dengan kesinambungan kelentangan Dayak Benuaq di Kalimantan Timur. Penelitian ini mnggunakan pendekatan etnografi, yakni melihat dan mendeskripsikan musik tidak hanya sebagai bunyi itu sendiri, melainkan bagaimana musik sebagai hasil dari serangkaian aktivitas tertentu. Pendekatan ini dipilih ini karena sejalan dengan tujuan 
penelitian ini, yakni tidak hanya melihat kelentangan sebagai bunyi semata, melainkan bagaimana ia dipelajari, ditransmisikan dari satu pihak ke pihak lain, dan bagaimana ia diterima oleh masyarakat sehingga tetap bertahan.

\section{Arti Kelentangan?}

Kelentangan, dalam masyarakat Dayak Benuaq di Kalimantan Timur, memiliki setidaknya tiga dimensi arti. Pertama, dalam lingkup yang paling kecil, kelentangan adalah sebuah instrumen musik berupa enam buah gong berpencu yang diletakkan secara horizontal-berderet dalam sebuah dudukan yang umumnya terbuat dari kayu. Instrumen ini dimainkan oleh satu orang dengan menggunakan sepasang pemukul.

Kedua, dalam lingkup yang lebih luas, kelentangan merupakan penyebutan atau nama suatu ansambel musik yang terdiri dari instrumen kelentangan itu sendiri (yakni enam buah gong berpencu), gimar (gendang silindris dengan membran ganda, dimainkan oleh satu orang dengan dua pemukul), genikng (gong gantung vertikal yang ukurannya lebih besar daripada instrumen kelentangan, serupa dengan kempul dalam gamelan Jawa), dan sulikng dewa (suling vertikal, terbuat dari material bambu). Penggunaan nama salah satu instrumen-biasanya instrumen yang paling dominan dalam permainannya - untuk menyebut suatu ansambel merupakan hal yang jamak dijumpai. Contoh: ansambel gambus, yang terdiri dari instrumen gambus, marawis, dan sebagainya; ansambel calung, yang terdiri dari instrumen calung, dhendhem, gong, kendhang, dan sebagainya. Contoh salahsatu pola kelentangan untuk iringan belian bawosebagai berikut. 

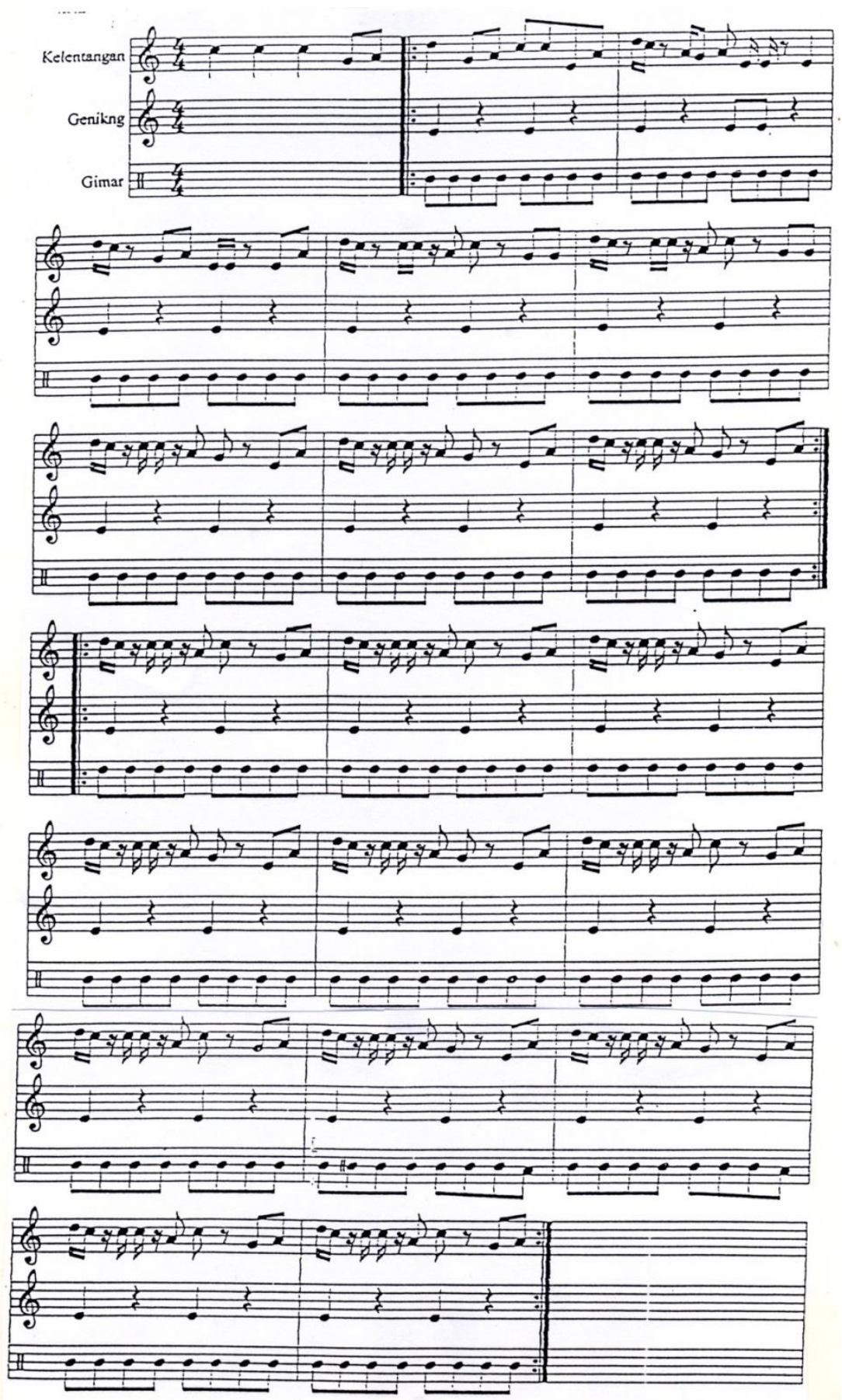

Ketiga, dalam lingkup yang paling luas, kelentangan merupakan suatu praktik musikal dengan instrumen dan ansambel tertentu, beserta dengan repertoar, konteks penyajian, aturan-aturan tertentu yang pada gilirannya menghasilkan estetika tertentu pula yang kemudian tertanam dalam pemahaman masyarakat pemiliknya. Dengan kata 
lain, kelentangan bukan saja mengacu pada soal material atau kebendaan, melainkan juga pada tataran konseptual. Ketiga dimesi arti kelentangan ini tidaklah terpisah secara kaku dan mutlak antara satu dengan lainnya; sebaliknya ketiga dimensi arti ini saling berkaitan.

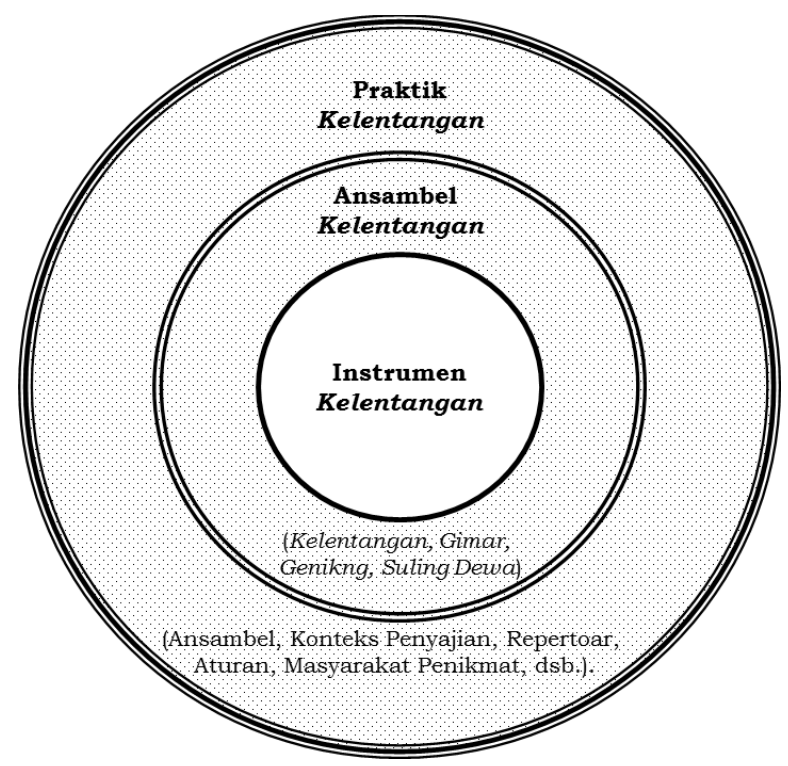

Instrumen, Ansambel, dan Praktik Kelentangan dalam Masyarakat Dayak Benuaq

\section{Proses Transmisi dan Kesinambungan Kelentangan}

Etnomusikolog Kay Kaufman Shelemay mendefinisikan transmisi musik sebagai "communication of musical materials from one person to another, whether in oral, aural, or written forms, without regard to the time depth of the materials transmitted" (Kaufman, 2008: 154). Jadi, Secara sederhana, transmisi dapat diartikan sebagai pemindahan sesuatu (informasi, pesan, atau semacamnya) dari pengirim kepada penerima. Artinya, transmisi merupakan sebuah proses komunikasi. Berpijak pada konsep komunikasi, maka ada beberapa elemen esensial yang niscaya ada dalam sebuah transmisi, yakni pengirim transmisi, penerima transmisi, pesan yang ditransmisikan, dan cara transmisi. Agar sebuah pesan, amanat, atau informasi dapat bertahan atau dapat tetap eksis seiring berjalannya waktu, maka ia harus terus-menerus ditransmisikan.

Sebagai sebuah bentuk komunikasi, proses transmisi musik secara garis besar dapat dipisahkan menjadi dua tahap, yakni pengiriman pesan dan penerimaan. Menurut Kuczynski, Marshall dan Schell (S. Marshall, \& K. Schell, 2009: 5) terjadi 
eksternalisasi di pihak pengirim pesan (dalam hal ini guru/pemain musik), sementara pihak penerima (dalam hal ini calon pemusik atau penonton) mengalami internalisasi. Baik eksternalisasi maupun internalisasi di masing-masing pihak ini, dalam kasus transmisi kelentangan, terjadi tanpa disadari. Ini antara lain terjadi karena proses transmisi tidak terjadi dalam suatu setting yang formal dan eksklusif yang dapatdisebut dengan kegiatan "pembelajaran" atau "belajar-mengajar".

Kelentangan sangat terkait erat dengan aktivitas lain. Ia bukanlah sebuah sajian musik mandiri, melainkan lekat dengan kegiatan lain dalam kehidupan masyarakat Benuaq, misalnya upacara adat. Oleh karen itu, proses pembelajaran terjadi dalam perhelatan-perhelatan yang menghadirkan kelentangan. Di situ lah seorang calon penu'ung bisa melihat dan bersinggungan dengan kelentangan. Dalam penelitian ini, penulis menyoroti empat konteks penyajian kelentangan, yakni tari gantar yang sifatnya hiburan; upacara belian (penulis mengambi belian bawo dan belian sentiu), yakni upacara ritual berskala kecil; dan kwangkay, sebuah upacara ritual lokal yang berskala besar.

Gantar merupakan salah satu bentuk tarian yang ada dalam masyarakat Dayak Benuaq di Desa Tanjung Isuy, Kalimantan Timur. Tarian ini merupakan tari pergaulan yang dilakukan berkelompok, penarinya adalah kaum wanita. Tarian ini diiringi oleh ansambel kelentangan yang lazimnya terdiri dari instrumen kelentangan itu sendiri, gimar, dan genikng. Irama musik sifatnya mengalir, tanpa ada aksentuasi-aksentuasi tertentu yang khusus ditujukan untuk memberi tekanan pada gerak penari seperti yang umum dijumpai dalam permainan kendhang yang mengiringi tari Jawa. Permainan gimar, yaitu gendang dalam ansambel kelentangan, justru berperan menunjang melodimelodi yang dibawakan oleh instrumen utama. Di sini fungsi gimar bukan sebagai pemimpin tunggal yang mutlak.

Aktivitas-aktivitas hiburan seperti tari gantar merupakan ajang yang sangat terbuka bagi seseorang yang ingin mempelajari kelentangan. Seseorang yang tertarik untuk bisa memainkan kelentangan dapat melihat, memperhatikan dengan seksama atau menyimak (bekajiq) permainan para penu'ung (pemusik kelentangan) yang lebih senior mengiringi tari gantar. Tidak jarang si calon penu'ung ini ikut langsung dalam formasi pengiring, mengimitasi atau (kintau) apa yang dilihatnya. Biasanya keikutsertaan seperti ini dimulai dari memainkan instrumen yang paling mudah diingat dan ditiru pola 
tabuhannya, yakni genikng. Pemain genikng hanya perlu membunyikan instrumennya setiap 8 hitungan untuk memberi tekanan pada jalinan melodi yang dimainkan pada instrumen kelentangan.

Setelah dirasa cukup mampu oleh penu'ung yang lebih senior karena dapat mengikuti permainan dengan baik, pemain genikng pemula biasanya didorong untuk mencoba memainkan instrumen lainnya, yakni gimar. Selain karena didorong, mencoba mempelajari instrumen lain juga bisa karena dorongan si pemain sendiri, tapi tentu dengan seizin pemain lainnya yang lebih senior. Demikian pula setelah dianggap mengusai permainan gimar dalam mengiringi tari gantar, seseorang bisa beranjak untuk mempelajari instrumen kelentangan, yakni instrumen yang pola permainannya paling kompleks dalam ansambel ini.Pada dasarnya rangkaian proses di atas tidak diatur secara baku, namun sudah menjadi tahapan lazim yang dilalui oleh seorang penu'ung yang baru mulai mempelajari kelentangan, yakni dari instrumen yang teknik permainannya sederhana hingga yang kompleks. Proses ini juga ditujukan agar penu'ung yang baru belajar bisa familiar dengan komposisi yang dimainkan. Sebenarnya tidak ada istilah penu'ung junior atau senior dalam masyarakat Dayak Benuaq; kedua istilah ini penulis pinjam untuk membedakan yang baru belajar dan yang sudah lebih dulu belajar.Proses belajar para penari gantar pada dasarnya juga tidak berbeda dengan penu'ung. Siapa saja boleh ikut berpartisipasi dalam tarian. Proses seperti ini nampaknya merupakan cara belajar yang umum dijumpai dalam kebudayaan-kebudayaan masyarakat Dayak di Kalimantan, seperti yang juga dijumpai olehJudith Hudson di wilayah Kalimantan Tengah (Hudson, 1971: 134-135).

Konteks lain yang menghadirkan kelentangan adalah belian. Dalam kehidupan masyarakat Dayak di Kalimantan, terdapat beragam beliandengan kegunaan yang beragam pula. Dalam masyarakat Benuaq saja, misalnya, dikenal beberapa jenis belian, antaralain belian sentiu, belian sipung, belian bawo,belian kenyong dewa, belian nalith tautn, belian ngeragag, belian banyukng, danbelian melas anak. Beragam belian tersebut digunakan baik untuk keperluan-keperluan positif—-keperluan yang baik, dalam arti menolong, membantu, mengobati orang-maupun untuk yang sifatnya negatif atau tergolong tindak kejahatan, contohnya menghancurkan kehidupan seseorang, membunuh seseorang dari jarak jauh atau yang dikenal dengan parangmaya, dan sebagainya. Pada prinsipnya, belian merupakan cara yang diyakini dapat 
menghubungkan dunia manusia dengan para penguasa "dunia lain", baik penguasa dunia atas maupun penguasa dunia bawah.Untuk penelitian ini, penulis mengambil dua jenis belian guna memberikan gambaran yang lebih luas terkait kelentangan dalam jenis upacara ini, yakni belian bawo dan belian sentiu.

Belian bawodan belian sentiu merupakan ritual untuk menyembuhkan segala macam penyakit terutama yang disebabkan oleh gangguan makhluk halus. Belian bawo diyakini oleh masyarakat lokal ampuh dan mujarab untuk menyembuhkan penyakit yang tidak bisa disembuhkan secara medis, karena penyakit itu, menurut kepercayaan mereka, disebabkan oleh gangguan makhluk halus. Sementara itu, belian sentiumerupakan belian khusus untuk mengobati atau menyembuhkan berbagai macam penyakit selain juga sebagai upaya untuk menangkal wabah penyakit yang akan menyerang masyarakat setempat, terutama yang diyakini disebabkan oleh kutukan dan gangguan roh-roh jahat atau uwokng.

Agak berbeda dengan saat digunakan mengiringi tari gantar, kelentangan dalam belian bawo dan belian sentiu harus mengikuti instruksi-instruksi dari pemimpin ritual, yakni pemeliatn. Kapan kelentangan dimainkan, dengan tempo seberapa dan bagaimana dinamikanya, tergantung pada tahapan prosesi. Penu'ung yang mengiringi upacaraupacara ritual adalah mereka yang dianggap sudah pantas, yakni sudah memiliki kemampuan teknis yang baik dalam mainkan instrumen dan juga sudah mengetahui aturan-aturan atau jalannya ritual serta instruksi-instruksi dari pemeliatn. Kendati demikian, pada prinsipnya tidak ada standar baku yang dijadikan ukuran apakah seorang penu'ung sudah layak atau belum untuk mengiringi upacara ritual seperti belian.

Seseorang yang baru belajar belum diperkenankan ikut serta untuk mengiringi ritual yang dianggap sakral oleh masyarakat. Kendati demikian, seseorang yang berminat untuk meminkan kelentangan bisa menyimak permainan-permainan para penu'ung dengan bebas, karena penyajian kelentangan ini bisa dilihat dari jarak sangat dekat oleh siapa saja. Tidak adat batasan antara masyarakat-partisipan upacara dengan para penu'ung. Senior-tidaknya seorang penu'ung adalah berdasarkan pengakuan dari sesama penu'ung dan juga dari masyarakat, yang diukur dengan berapa lama mereka konsisten menggeluti memainkan ansambel ini dan penguasaannya terhadap permainan kelentangan dan pengetahuannya terhadap ritual (Wawancara dengan bapak Nawan). Tidak ada laku khusus yang harus dijalani untuk menjadi penu'ung. 
Dalam kesempatan-kesempatan ini para penu'ung muda mengamati permainanpermainan dari senior mereka, mempelajari komposisi yang dimainkan dan juga jalannya ritual. Saat seperti ini pula lah seorang calon penu'ung (yakni seseorang yang tertarik dengan kelentangan dan ingin bisa memainkannya) mengamati, memperhatikan permainan kelentangan, dan bisa mencobanya saat jeda, istirahat, atau seusai ritual. Umumnya ia tidak bisa langsung menirukan atau mempraktikkan apa yang dilihatnya saat itu juga, karena dalam ritual yang dianggap sakral, kesalahan dalam mengiringi diyakini bisa membuat roh-roh yang dipanggil tidak berkenan (Wawancara dengan bapak Nawan).

Selain belian, ritual Dayak Benuaq lainnya yang menggunakan kelentangan adalah upacara kwangkay. Kwangkay merupakan salah satu upacara Dayak Benuaq yang berkaitan dengan kematian. Pokok dari upacara ini adalah pemindahan tulangbelulang orang yang sudah meninggal dari pemakaman terdahulu, dibawa ke dalam lamin untuk diupacarai, yang dimaksudkan untuk mengantarkan roh yang bersangkutan ke alam Lamut, yakni alam roh. Setelah upacara, kerangkadisimpan seterusnya dalam peti kayu yang disebut lungun, yang ditempatkan di sekitar lamin. Oleh karena itu, dalam literatur-literatur yang ditulis oleh peneliti asing, kwangkay disebut sebagai secondary burial atau secondary mortuary, yakniupacara pemakaman kedua.

Masih sama halnya seperti dalam belian bawo dan belian sentiu, penyajian kelentangan dalam kwangkay juga mengikuti alur upacara. Dalam upacara ini,kelentangan antara lain mengiringi tarian yang disebut ngerangkau. Jika penu'ungnya adalah mereka yang dianggap sudah menguasai permainan dan memiliki pengetahuan tentang upacara, maka tidak demikian halnya dengan para penarinya. Siapa saja diperkenankan untuk ambil bagian dalam tari ngerangkau, mulai dari anak-anak hingga orang tua, laki-laki ataupun perempuan. Mereka yang menari umumnya adalah para kerabat dari orang meninggal yang kerangkanya diupacarai serta warga sekitar di kampung itu.

Konteks-konteks yang diuraiakan di atas merupakan sebagian lembaga pembelajaran praktik musikal itu. Dalam masyarakat Dayak Benuaq di Tanjung Isuy, tidak ada lembaga khusus yang memang diperuntukkan bagi pembelajaran kelentangan maupun praktik-praktik kesenian lainnya. Berbeda halnya dengan begitu banyaknya 
sanggar yang dapat dijumpai di Jawa dan Bali misalnya, masyarakat Benuaq tidak mengenal model pembelajaran seperti ini.

Selanjutnya, tidak ada pula waktu yang dikhususkan untuk seseorang mempelajari kelentangan. Momen untuk bersinggungan dan mempelajari kelentangan adalah ketika ia disajikan dalam aktivitas-aktivitas publik, baik yang sifatnya profan atau sakral, seperti yang telah dipaparkan di atas. Biasanya, saat jeda istirahat, seorang pemula bisa menirukan permainan-permainan para penu'ung yang sudah disimaknya sebelumnya. Proses pengiriman informasi materi musikal kelentangan nyaris sepenuhnya bersifat aural. Hanya sedikit adanya instruksi-instruksi verbal lisan dari penu'ung senior kepada seorang pemula yang sedang belajar soal bagaimana memainkan kelentangan.

Dalam upacara-upacara ini juga lah seorang pemula belajar tentang ketentuanketentuan jalannya upacara, urutannya, dan hal-hal lain yang berkaitan. Tidak ada pembelajaran yang khusus mempelajari adat-istiadat ini. Semuanya dipelajari sambil dilakukan. Dengan kata lain, aktivitas publik yang melibatkan kelentangan adalah "kelas" untuk mempelajari musik itu. Semakin sering seseorang bersinggungan dengan aktivitas seperti itu, maka kemungkinan besar makin familiar dengan kelentangan, baik dalam hal keterampilan teknis maupun pengetahuannya soal upacara-upacara yang melingkupinya.

Berdasarkan uraian proses transmisi kelentangan di atas, setidaknya ada tiga hal utama yang dapat diambil sebagai inti. Pertama, transmisi berlangung antara penu'ung dengan penu'ung;kedua, transmisiterjadi juga antara penu'ung dengan masyarakat atau penonton; danketiga, keberadaan kelentangan dalam masyarakat Dayak Benuaq sangat bergantung pada aktivitas-aktivitas non-musikal, yakni perhelatan upacara atau ritual yang diselenggarakan oleh masyarakat. Berikut ini akan dibahas satu per satu dari ketigapokok tersebut untuk melihat bagaimana keterkaitan transmisi dengan kesinambungan praktik kelentangan.

Transmisi antara penu'ung dengan penu'ung, atau bisa dikatakan penu'ung junior dengan penu'ung senior, pada prinsipnya merupakan pembelajaran keterampilan dan juga pengetahuan tentang musik kelentangan serta aktivitas yang melingkupi penyajiannya.Keterampilan dan pengetahuan ini diwariskan melalui interaksi langsung antara penu'ung junior-senior dalam berbagai aktivitas yang menghadirkan 
kelentangan.Tidak ada pranata khusus yang diperuntukkan bagi pembelajaran kelentangan.

Saat ini, dalam masyarakat Benuaq di Tanjung Isuy, dapat dikatakan ada dua generasi penu'ung atau pemain kelentangan. Penyebuatan atau kategorisasi generasi ini penulis dasarkan pada usia mereka. Generasi senior adalah Bapak Nawan (60 tahun, memainkan instrumen kelentangan dan sulikng dewa), Bapak Pesan (55 tahun, memainkan instrumen gimar), dan Bapak Moder (70 tahun, memainkan instrumen genikng), sedangkan generasi junior terdiri dari Bapak Ayeng (37 tahun, memainkan instrumen kelentangan dan sulikng dewa), Bapak Katuk (36 tahun, memainkan gimar), dan Bapak Murji (45 tahun, memainkan genikng).

Bapak Nawan mulai memainkan kelentangan pada usia 3 tahundari kakah atau kakeknya yang bernama kakah Dangut. Ia tertarik memainkan kelentangan karena begitu sering menyaksikannya, saat diajak sang kakek menghadiri berbagai macam upacara tradisional Dayak Benuaq, terutamabelian dan kwangkay). Kakah Dangut sendiri adalah orang yang dianggap sebagai pemimpin dalam ansambel kelentangan.Bapak Nawan juga memainkan kelentangan agar bisa mengiringi pemeliatn dan bisa mewarisi ilmu belian dari sang kakek. Selain itu, saat usianya masih remaja,Bapak Nawan juga menekuni permainan kelentanganagar terlihat menonjol di mata para penari wanita. Sekarang, selain bisa memainkan kelentangan, Bapak Nawan juga dikenal sebagai guruq pemeliatn sentiu.

Bapak Pesan mulai memainkan kelentangan usia 5 tahun. Ia belajar dari bapaknya sendiri, yakni Pak Daman. Salah satu hal yang mendorong dirinya untuk bermain kelentangan adalah agar bisa mengiringi berbagai macam upacara adat masyarakat Benuaq, khususnya belian Sentiu dan belian bawo. Beliau sekarang dikenal sebagai guruq pemeliatn Sentiu dan Bawo.

Bapak Moder mulai memainkan kelentangan pada usia 5 tahun. Seperti halnya Bapak Nawan, Bapak Moder belajar dari kakeknya,kakah Itaq.Alasan dirinya menekuni permainankelentangan adalah agar bisa mengiringi berbagai macam upacara adat seperti belian dan kwangkay, yang dengan demikian ia dianggap memiliki kemampuan lebih atau menonjol di lingkungan pergaulannya. Selain itu, bisa bermain kelentangan merupakan salah satu cara untuk mendekati para penari wanita. Terbukti, sekarang Bapak Moder menikah dengan seorang penari gantar bernama Ainah. 
Bapak Ayeng mulai memainkan kelentangan sejakusia 10 tahun, ia belajar dari temannya yaitu, bapak Moder. Alasannya mempelajarikelentangan adalah agar bisa mengiringi berbagai tarian pergaulan seperti tari gantar, tari gong, tari perang, dan lainlain, sehingga pada gilirannya bisa berkenalan dengan penari wanita (Bimba) yang sekarang menjadi isterinya.

Bapak Katuk mulai belajar memainkan kelentangan sejakusia 3 tahun dari bapaknya, Nawan. Iamemainkankelentangan agar bisa menjadi seperti sang bapak, menjadi pengiring berbagai macam upacara tradisional Dayak Benuaq, khususnya belian dan kwangkay. Ada juga keinginan dalam dirinya untuk mewarisi dan mempertahankan kesenian tradisional agar tidak punah.

Bapak Murji mulai belajar memainkan kelentangan sejak usia 5 tahundari bapaknya, Sardi.Salah satu alasan yang mendorongnya menekunikelentangan adalah agar bisamengiringi para penari wanita dan agar terlihat lebih menonjol di mata para peserta upacara adat.

Generasi penu'ung yang lebih muda, seperti yang diuraikan sekilas di atas, mengakuisisi kemampuan dari generasi yang lebih tua dengan cara menyimakmelihat, mendengar, memperhatikan dengan seksama-permainan kelentangan dalam beragam konteks penyajian, lalu kemudian mempraktikkan atau mengimitasi apa yang sudah dilihat dan didengarnya. Seperti yang telah disinggung di atas, tidak ada pranata khusus dalam masyarakat Benuaq yang memang diperuntukkan bagi pembelajaran kelentangan maupun bentuk-bentuk praktik kesenian lainnya.

Uraian di atas memperlihatkan bahwa seringkali transmisi kelentangan antar generasi terjadi dalam satu keluarga atau garis keturunan.Kendati demikian, tidak ada keyakinan masyarakat lokal bahwa untuk menjadi penu'ung, seseorang harus memiliki darah keturunan penu'ung.Transmisi dalam satu keluarga terjadi lebih karena intensifnya dorongan yang diberikan oleh generasi yang lebih tua (misalnya ayah) kepada generasi yang lebih muda (anak).Interaksi antara sumber pengetahuan dengan penerima pengetahuan terjadi secara terus menerus sehingga transmisi berjalan dengan baik.Alhasil, ilmu dari generasi yang lebih tua pada gilirannya dapat diakuisisi oleh generasi yang lebih muda.

Transmisi antar-pelaku ini, kendati demikian, tidak dapat berlangsung tanpa tersedianya konteks yang menjadi wadah aktivitas kelentangan. Yang dimaksud dengan 
konteks yang menjadi wadah aktivitas kelentangan adalah berbagai aktivitas yang melibatkan musik tersebut, baik yang sifatnya profan maupun sakral.Upacara ritual merupakan salah satu konteks penting dalam hal ini.Semakin sering diadakan upacara ritual, maka semakin sering pula kelentangan digelar.Artinya, semakin terbuka pula ruang untuk terjadinya tranmisi pengetahuan dan keterampilan antar-penu'ung.

Upacara ritual dilakukan oleh warga masyarakat Benuaq.Lebih dari itu, masyarakat Benuaq tetap melaksanakan praktik-praktik ritual lokal karena masih memegang teguh kebudayaan mereka.Jadi, sedikit-banyak, langsung ataupun tidak langsung, Warisan-warisan pengetahuan dan keyakinan leluhur Dayak Benuaq mendorong masyarakat untuk tetap menggelar berbagai macam upacara ritual yang melibatkan juga kelentangan dalam penyelenggaraannya. Semakin sering digelar upacara, maka semakin sering kelentangan disajikan, dan ruang bagi transmisi kelentangan akan semakin terbuka. Demikian pula sebaliknya.

Saat penyajian kelentangan dalam suatu ritual misalnya, tidak hanya terjadi interaksi antar-penu'ung, melainkan juga antara penu'ung dengan publik yang hadir. Sadar ataupun tidak, masyarakat yang ada di tempat itu mengakuisisi pengetahuan tentang kelentangan, antara lain apa itu kelentangan, bagaimana bunyi-bunyian yang dihasilkan, siapa yang memainkannya, bagaimana posisinya dalam ritual, dan kebiasaan-kebiasaan lainnya.Transmisi yang terjadi antara antara penu'ung dengan publik lebih merupakan transmisi pengetahuan, bukan keterampilan.

Pengetahuan yang diresapi oleh masyarakat Benuaq sebagai pemilik kelentangan ini kemudian menjadi standar bagaimana praktik kelentangan yang semestinya. Pengetahuan masyarakat ini menjadi acuan tentang "bagaimana kelentangan dan seperti apa ia ketika disajikan dalam konteks tertentu”. Dengan kata lain, pengetuan yang terbangun di pihak masyarakat memberikan umpan balik pagi praktik kelentangan di kalangan penu'ungnya. Ini sejalan dengan yang dikemukakan Alan Merriam tentang bagaimana konsep mempengaruhi bunyi musik: "there is a constant feedback from the product to the concepts about music, and this is what accounts both for change and stability in music system” (Merriam, 1964: 33). Model ini membentuk sebuah siklus, dimana konsep mempengaruhi perilaku yang menghasilkan bunyi. Ada umpan balik yang konstan dari produk terhadap konsep musik, dan hal inilah yang menyebabkan sebuah sistem musik dapat berubah namun tetap stabil. 
Namun, tentu saja tidak semua individu dalam masyarakat Benuaq memiliki tingkat pemahaman yang sama dalam meresapi kelentangan dalam kebudayaan mereka.

\section{Penutup}

Berdasarkan paparan di atas, dapat diambil simpulan-simpulan tentang transmisi dan keterkaitannya dengan kesinambungan kelentangan berikut ini.

Pertama, tranmisi kelentangan, berdasarkan pelaku transmisinya, dapat dibedakan menjadi dua, yaitu tranmisi antar-penu'ung dan transmisi antara penu'ung dengan publik, yaitu masyarakat pendukungnya.Transmisi antar-penu'ung, yakni dari generasi yang lebih tua kepada generasi yang lebih muda merupakan transmisi yang memuat pengetahuan dan keterampilan praktis.Transmisi antar-penu'ung sejauh ini cenderung terjadi dalam lingkup satu keluarga, yakni, misalnya dari ayah kepada anak atau dari kakek kepada cucu. Ini tidak disebabkan karena adanya ketentuan bahwa status penu'ung merupakan keturunan (ascribed), melainkan lebih karena interaksi antar mereka yang berada dalam satu keluarga lebih intensif sehingga dapat mendorong seseorang untuk lebih intesif bersinggungan dengan kelentangan.Sementara itu, transmisi antara penu'ung dengan masyarakat lebih bersifat transmisi pengetahuan, bukan kemampuan praktis. Transmisi ini membangun pemahaman atau konsep dalam masyarakat tentang apa itu kelentangan dan bagaimana kelentangan yang "semestinya".

Kedua, transmisi pengetahuan dan keterampilan antar-penu'ung maupun transmisi pengetahuan antara penu'ung dengan masyarakat tidak dapat terjadi apabila upacara-upacara ritual atau aktivitas lain yang menjadi konteks penyajian kelentangan tidak digelar. Kelentangan merupakan sajian yang sangat terkait dengan konteks, ia bukanlah sebuah sajian musik mandiri. Lebih jauh lagi, upacara-upacara ritual ini masih dilaksanakan oleh masyarakat Benuaq karena mereka masih memegang teguh ajaranajaran leluhur. Jadi, transmisi kelentangan akan berjalan dengan baik ketika konteks penyajiannya masih digelar. Sebaliknya, transmisi tidak dapat berjalan dengan baik jika konteksnya tidak lagi digelar, padahal konteks ini merupakan ruang utama terjadinya transmisi.

Ketiga, transmisi yang terjadi seperti diuraikan di atas tidak saja memunculkan regenerasi penu'ung, melainkan juga regenerasi masyarakat pendukungya. Baik 
regenerasi penu'ung maupun regenerasi masyarakat pendukung kelentangan memiliki peran yang sama pentingnya. Regenerasi penu'ung saja tidak cukup mampu menunjang kesinambungan kelentangan tanpa didukung oleh regenerasi masyarakat pendukungnya, yakni mereka yang menyediakan konteks penyajian bagi musik itu.Sebaliknya, regenerasi masyarakat pendukung saya juga tidak dapat menjamin kesinambungan praktik kelentangan tanpa regenrasi pelakunya.

Keempat-berdasarkan kesimpulan kedua di atas-menjaga kesinam-bungan kelentangan dalam masyarakat Dayak Benuaq berarti tidakdapat hanya berhenti pada mengintensifkan transmisinya saja, melainkan juga haris memperhatikan konteks penyajian yang menjadi ruang utama bagi berlangsungnya transmisi itu.Artinya, kesinambungan praktik kelentangan tidak hanya ditopang oleh transmisi yang baik.Lebih dari itu, dalam jangka panjang, kesinambungan suatu praktik musik didukung oleh infrastruktur atau ekosistem kebudayaan yang baik, yang setidaknya meliputi pelaku praktik musik itu sendiri, masyarakat pemiliknya, serta pemahaman dan kesadaran masyarakat yang bersangkutan untuk tetap menjalankan praktik-praktik budayanya.Dalam kebudayaan Dayak Benuaq, transmisi berlangsung secara aural-oral dalam aktivitas-aktivitas ritual yang sakral maupun kegiatan profan. 


\section{Daftar Pustaka}

\section{A.Tercetak}

Campbell, Patricia Shehan. "Teachers Studying Teachers: Pedagogical Practices of Artist Musicians," dalam Timothy Rice, ed. Ethnomusicological Encounters with Music and Musicians: Essays in Honor of Robert Garfias. London: Ashgate, 2011.

Haryono, Timbul. Seni Pertunjukan dan Seni Rupa dalam Perspektif Arkeologi Seni. Surakarta: ISI Press, 2008.

Hudson,Judith M. "Some Observations on Dance in Kalimantan".Indonesia Vol. 12, Oktober 1971, 134-135.

Merriam, Alan P. The Anthropology of Music.Evanston, IL: Northwestern University Press, 1964.

Pieterse, Jan Nederveen. Globalization and Culture: Global Mélange. Maryland: Rowman \& Littlefield Publishers, Inc., 2009.

Schönpflug,Ute. "Introduction to Cultural Transmission: Psychological, Developmental, Social, and Methodological Aspects", dalam Ute Schönpflug, ed. Cultural Transmission: Psychological, Developmental, Social, and Methodological Aspects. Cambridge: Cambridge University Press, 2009.

Shelemay, Kay Kaufman. "Ethnomusicologist, Ethnographic Method, and the Transmission of Tradition," dalam Gregory F. Barz \& Timothy J. Cooley, eds. Shadows in the Field: New Perspectives for Fieldwork in Ethnomusicology, Edisi Kedua. New York: Oxford University Press, 2008.

\section{Narasumber}

Nawan,70 Tahun, guruq pemeliatn sekaligus gurug penu'ung di desa Tanjung Isuy. Kalimantan Timur.

Moder, 60 Tahun, penu'ung di desa Mancong, tanggal 25 Agustus 2013, Kalimantan Timur. 